\title{
Silicon application positively alters pollen grain area, osmoregulation and antioxidant enzyme activities in wheat plants under water deficit conditions
}

\section{Kobra Maghsoudi a, Yahya Emam ${ }^{b}$, Muhammad Ashraf ${ }^{c}$, Mohammad Pessarakli ${ }^{\text {d, }}$ Mohammad Javad Arvin e}

${ }^{a}$ Postdoctoral Scholar, University of Advanced Technology, Kerman, Iran.

${ }^{\mathrm{b}}$ Department of Crop Production and Plant Breeding, College of Agriculture, Shiraz University, Shiraz, Iran.

${ }^{c}$ University College of Agriculture, University of Sargodha, Sargodha, Pakistan.

${ }^{\mathrm{d}}$ School of Plant Sciences, The University of Arizona, Tucson, AZ 85721, USA.

e Department of Horticulture, College of Agriculture, Shahid Bahonar University of Kerman, Kerman, Iran.

* Corresponding author. Email: pessarak@email.arizona.edu

\begin{abstract}
Role of exogenously-applied Si on antioxidant enzyme activities was investigated in wheat under drought stress using a completely randomized factorial design with four replications. Drought stress significantly enhanced activities of ascorbate peroxidase, peroxidase, superoxide dismutase and catalase, and elevated accumulation of osmotically active molecules, soluble sugars and proline. Si application further enhanced activities of enzymes involved in oxidative defense system and accumulation of osmotically active molecules in drought-stressed plants. Under drought stress conditions, water shortage decreased protein content in all cultivars; however, application of Si increased it. Pollen area ratio was lower than 1 for cvs. Shiraz and Marvdasht under drought, but greater than 1 for cvs. Chamran and Sirvan. Water-limited regimes resulted in decreased leaf $\Psi_{W}$ in all cultivars, but Si supply was effective in improving $\Psi_{\mathrm{w}}$ under water-limited regimes. Water shortage increased leaf
\end{abstract}


$\mathrm{K}, \mathrm{Mg}$, and $\mathrm{Ca}$ concentrations. Under drought stress, Si-treated plants had higher $\mathrm{K}$ concentration than the none-treated plants.

Keywords: Pollen grain, Proline, Protein, Soluble sugars, Wheat.

\author{
Abbreviations: \\ APX: Ascorbate peroxidase; CAT: Catalase; PEG: Polyethylene glycol 6000; POD: \\ Peroxidase; ROS: Reactive oxygen species; SOD: Superoxide dismutase; $\boldsymbol{\Psi}_{\mathbf{w}}$ : Leaf water \\ potential; Si: Silicon (sodium silicate).
}

\title{
Introduction
}

Wheat (Triticum aestivum L.), as a widely grown important food crop, is affected by adverse environments. Shortage of water is the premier factor of wheat productivity decline in many regions of the world (Lobato et al. 2008; Costa et al. 2011). Plants respond to stressful environments by regulating a myriad of metabolic processes. Of these processes, generation of reactive oxygen species (ROS) (Xu et al. 2008; Ashraf 2009). Although at low levels ROS play a vital role in stress signaling pathways (Raghu, Platela, and Srinivasan 2007), at higher levels, they trigger oxidative stress in plants, which results in damaging the biological membranes of key cellular organelles (Yordanov, Velikova, and Tsonev 2000). However, to counteract the ROS, plants generally produce a variety of antioxidant molecules, enzymatic and non-enzymatic. Of the antioxidant enzymes known, superoxide dismutase (SOD), peroxidase (POD), catalase (CAT), ascorbate peroxidase (APX), and glutathione reductase (GR) are considered to be the key enzymes for counteracting ROS (Ashraf 2009). However, a number of reports show that a close association exists between elevated activities of antioxidant enzymes and enhanced tolerance to stressful cues in crops such as sugar beet (Bor, Ozdemir, and Turkan 2003) and rice (Guo et al. 2006; Khanna-Chopra and Selote 2007). 
Under water stress conditions, shoots with the ability to maintain a relatively high amount of water may increase plant performance (Morgan and Tan 1996). The maintenance of high amount of water by the shoots may occur mainly due to an accumulation of organic osmotica, a process which is referred to as osmotic adjustment (Reddy, Chiatanya, and Vivekanandan 2004; Zhu et al. 2005). This process is a significant adaptation mechanism under scarce moisture regimes (Morgan 1980; Rontein, Basset, and Hanson 2002; Hummel et al. 2010). From a number of organic osmotica reported in plants, proline, soluble carbohydrates, organic acids, and amino acids play a vital role in osmoregulation (Zhu et al. 2005; Mittler 2006; Ashraf and Foolad 2007; Lobato et al. 2008). Mittler (2006) reported that the synthesis of proline is an effective metabolite involved in resistance of plants against stressful environments including drought stress. This statement was also confirmed by Teixeira and Pereira (2007).

The in-situ measurement of osmoregulation is an intricate process, but the measurement can be done by appraising the concentration of $\mathrm{K}$ in the tissue sap as $87 \%$ of the cellular solute is K (Morgan 1990). Morgan (1999) also reported that when pollen grain area ratio is greater than 1 the cultivar is capable of osmoregulation. Thus, it is also a good measure of osmoregulation in most plants.

Silicon ( $\mathrm{Si}$ ) is believed to play a beneficial role in plants grown under different stressful environments, e.g., water scarcity (Gong et al. 2005; Hattori et al. 2005; Shen et al. 2010; Maghsoudi, Emam, and Ashraf 2015; Maghsoudi et al. 2018; Maghsoudi et al. 2019), salinity (Ashraf et al. 2009), radiation stress (Shen et al. 2010), freezing stress (Liang, Zhu, and Li 2008), and toxicity (Feng et al. 2010). Silicon is believed to trigger a variety of metabolic processes in plants grown under stress (Gong et al. 2008; Maghsoudi, Emam, and Ashraf 2016). For example, cereal crops treated with Si can sustain drought-induced high leaf $\psi_{\mathrm{w}}$ (Ming et al. 2012). Furthermore, Si is known to promote the activities/levels of antioxidants 
to counteract the drought -induced generation of ROS (Gong et al. 2005; Li, Ma, and Shang 2007). It is now well evident that Si applied exogenously can mitigate the adverse effects of drought in most plants (Hattori et al. 2005; Liang et al. 2005; Maghsoudi, Emam, and Ashraf 2015). However, in most of the earlier reports, Si has been applied through the roots, but not many reports are available in the literature wherein the effects of foliar-applied Si have been examined. Thus, in the current investigation, the influence of foliar-applied Si on antioxidant enzyme activities, accumulation of osmotically active molecules and inorganic nutrients in some selected wheat cultivars under water- limited regimes were investigated. The response of pollen grains to osmotic stress and $\mathrm{Si}$ was also examined. The findings could add to a better elucidation of the mechanisms of Si-induced improvement in drought resistance of wheat cultivars.

\section{Materials and methods}

\section{Plant materials and growth conditions}

This experiment was carried out at the greenhouse of the College of Agriculture, Shiraz University (Badjgah), Iran, during the 2012- 2013 growing season using four wheat (Triticum aestivum L.) cultivars, Sirvan and Chamran (both drought tolerant), and Shiraz and Marvdasht (both drought sensitive). The light period in the greenhouse was maintained at 14 h/day with RH $55-60 \%$ and maximum and minimum temperatures of $28^{\circ} \mathrm{C}$ and $14^{\circ} \mathrm{C}$, respectively. Surface sterilization of all seed samples was done with $1 \% \mathrm{NaCl}$ solution for 10 min. For germination purpose, the sterilized seeds were placed in Petri plates each containing a wet filter paper. After 10 days the seedlings formed were planted in plastic pots. Each pot of $5 \mathrm{~L}$ size contained soil + sand in 2:1 ratio. The soil was classified as fine, mixed, mesic, Cacixerollic Xerochrepts. Urea was applied to each pot at $150 \mathrm{~kg} \mathrm{ha}^{-1}$ at transplantation (10 seedlings per pot). 
The experiment was a factorial based on a completely randomized design (CRD) with 4 replicates. There were 4 treatments for each wheat cultivar: regular watering with no Si foliar application, regular watering with $6 \mathrm{mM}$ Si foliar application, water shortage regime with no Si foliar application, and water shortage regime with $6 \mathrm{mM}$ Si foliar application. Until the anthesis stage, all pots were regularly irrigated by maintaining moisture content at $100 \%$ field capacity (F.C.). From anthesis to ripening, the water deficit treatment was maintained at $40 \%$ F.C., whereas the control pots were consistently maintained at $100 \%$ F.C. The source of Si was lab grade sodium silicate salt $\left(\mathrm{Na}_{2} \mathrm{SiO}_{3}\right)$ with no other additives, the $\mathrm{pH}$ of the solution was maintained at $6.5 \mathrm{Si}(6 \mathrm{mM})$ was applied for three consecutive days to the foliage at the tillering and anthesis stages. An equal amount of distilled water was sprayed to the plants not receiving Si treatment.

\section{Pollen grain experiment}

Pollen grain experiment was conducted on plants grown in control pots (100\% F.C.) to elude the adverse effects of water deficiency on pollen grains (Morgan 1980). Mature pollen grains, yet in the closed anthers, were soaked in 30\% polyethylene glycol 6000 (PEG), 30\% PEG plus silicon ( $\mathrm{Si}$ ), 50\% PEG, and 50\% PEG plus Si over a microscope slide. Solution of 50\% PEG was used as osmotic stress for pollen grains, while for the control, unstressed pollen grains were placed in a $30 \%$ PEG solution. $\mathrm{KCl}$ solution $(10 \mathrm{mM})$ was added to the solutions. The slides containing pollen were covered, incubated at room temperature for $24 \mathrm{~h}$, and viewed under amicroscope at $\times 200$ magnifications. Fifteen photos were taken as described by Morgan (1980). The Scion Image software was employed to measure the projected area of each pollen grain in micrometer. Then, the ratio of the pollen grain area under $50 \%$ to $30 \%$ PEG was calculated. 


\section{Determination of soluble sugars, proteins, and proline}

In the grain filling stage, the flag leaves from each treatment were taken and immersed in double-distilled water. The same flag leaves from each treatment were pooled and transferred to liquid $\mathrm{N}_{2}$ until the determination of organic metabolites, i.e., soluble sugars, proteins, proline, enzymes.

Soluble sugars were appraised following Zhang et al. (2006). Dry leaf samples were placed in boiling distilled water contained in a water bath for $30 \mathrm{~min}$. The mixture was subjected for 10 min to centrifugation at $8000 \mathrm{~g}$. To an aliquot of $0.5 \mathrm{ml}$ of the supernatant $1.5 \mathrm{ml}$ of distilled water and $0.5 \mathrm{ml}$ of $5 \%$ phenol and $5 \mathrm{ml}$ of concentrated $\mathrm{H}_{2} \mathrm{SO}_{4}$ were added. After vigorously shaking, the mixture was placed for one min in a boiling water bath. After cooling the mixture at room temperature, its color change was noted at $485 \mathrm{~nm}$ using a spectrophotometer. The protocol described by Bradford (1976) was employed for determining leaf soluble proteins and that of Bates, Waldran, and Teare (1973) for the free proline.

\section{Measurement of antioxidant enzyme activities}

The leaf samples were homogenized in ice-cold $1 \mathrm{ml}$ of $0.1 \mathrm{M}$ potassium phosphate buffer (pH 7.8) containing $1 \mathrm{mM}$ ethylene di-amine-tetra-acetic acid (EDTA) and $2 \%(\mathrm{w} / \mathrm{v})$ PVP. The mixture was centrifuged for $20 \mathrm{~min}$ at $12000 \mathrm{~g}$ at $4^{\circ} \mathrm{C}$, and the supernatant was used for enzyme activity determinations.

The superoxide dismutase activity (SOD) assay was based on the method modified by Dhindsa and Matowe (1981). Samples were homogenized in $5 \mathrm{ml}$ cold $50 \mathrm{mM}$ phosphate buffer ( $\mathrm{pH} 7.0$ ) containing $1 \mathrm{mM}$ EDTA, $0.05 \%$ triton, $2 \%$ polyvinylpolypyrrolidone (PVPP), and $1 \mathrm{mM}$ ascorbic acid. In the spectrophotometric assay, $1 \mathrm{ml}$ reaction mixture contained 50 mM phosphate buffer ( $\mathrm{pH} 7.8), 0.1 \mathrm{mM}$ EDTA, $13 \mathrm{mM}$ methionin, $75 \mu \mathrm{M}$ NBT, $2 \mu \mathrm{M}$ 
riboflavin and $50 \mu \mathrm{l}$ of plant extract. Riboflavin was added last and the reaction was initiated by placing the tubes under white fluorescent light. The reaction was terminated after $10 \mathrm{~min}$ by removal from the light source. The reaction product was measured at $560 \mathrm{~nm}$. The volume of supernatant corresponding to $50 \%$ inhibition of the reaction was assigned a value of 1 enzyme unit.

Peroxidase activity (POD) was determined according to the method of Cakmak, Strbac, and Marschner (1993) by monitoring the rates of guaiacol oxidation. Ascorbate peroxidase activity (APX) was determined by following the decrease of ascorbate and measuring the change in absorbance at $290 \mathrm{~nm}$ for $1 \mathrm{~min}$ in $2 \mathrm{ml}$ of a reaction mixture containing $50 \mathrm{mM}$ potassium phosphate buffer ( $\mathrm{pH} 7.0$ ), $1 \mathrm{mM}$ EDTA-Na2, $0.5 \mathrm{mM}$ ascorbic acid, $0.1 \mathrm{mM} \mathrm{H}_{2} \mathrm{O}_{2}$ and $50 \mu \mathrm{l}$ of crude enzyme extract at $25^{\circ} \mathrm{C}$ (Nakano and Asada, 1981). Catalase activity (CAT) was determined by monitoring the disappearance of $\mathrm{H}_{2} \mathrm{O}_{2}$ at $240 \mathrm{~nm}$ according to the method of Aebi (1984). The reaction mixture contained $50 \mathrm{mM} \mathrm{K-phosphate} \mathrm{buffer} \mathrm{(pH} \mathrm{7.0),}$ $33 \mathrm{mM} \mathrm{H}_{2} \mathrm{O}_{2}$, and enzyme extract.

\section{Analysis of mineral nutrients (K, Na, Mg and Ca)}

Dried and powdered leaf samples were digested in $0.1 \mathrm{~N}$ acetic acid. $\mathrm{Na}^{+}$and $\mathrm{K}^{+}$in the digested samples were quantified using a flame photometer (Corning 410, Essex, UK). Type of gas was natural gas. Wavelength for $\mathrm{Na}$ and $\mathrm{K}$ was 589 and $767 \mathrm{~nm}$, respectively (Hamada and EL-enany 1994). Ca and Mg were quantified using an atomic absorption (Shimadzu AA670) (Ryan, Estefan and Rashid 2007).

\section{Measurement of leaf water potential $\left(\Psi_{\mathrm{w}}\right)$}


In the grain filling stage, the leaf water potential $\left(\Psi_{\mathrm{w}}\right)$ was measured using a pressure chamber technique (PMS instrument company, ALBANY Oregon 97322). For each treatment, $\Psi_{\mathrm{w}}$ of five leaves were measured and then their average was calculated.

\section{Statistical analysis}

Data were subject to the analysis of variance (ANOVA) using the statistical package SAS 9.1. The experiment was set up as a $4 \times 2 \times 2$ factorial based on a completely randomized design (CRD) design with 4 replicates. The significant differences among all means within each variable were worked out using Duncan's multiple-range test at 5\% probability level. Also, the standard deviation was calculated and recorded.

\section{Results}

\section{Response of pollen grains}

Responses of pollen grains of the drought sensitive cv. Shiraz and drought resistant cv. Sirvan to osmotic stress under added silicon (Si) and without $\mathrm{Si}$ are shown in Figure 1 and Figure 2. Pollen area ratio was found to be lower than 1 under 50 to $30 \%$ of PEG for cvs. Shiraz and Marvdasht, while it was greater than 1 for cvs. Chamran and Sirvan. Also, Si treatment caused an increase in the pollen area ratio of all cultivars; however, increase in the pollen area ratio of cvs. Shiraz and Marvdash was greater than this increase in cvs. Sirvan and Chamran (Table 1).

\section{Osmotically active molecules (soluble sugars, proteins, and proline)}

The levels of soluble sugars increased significantly under water deficit (40\% F.C.) conditions (Table 2). A significant difference was found among the cultivars regarding the soluble sugars. The drought- resistant cultivars Sirvan and Chamran accumulated a higher amount of 
soluble sugars than that in the drought sensitive cvs. Shiraz and Marvdasht. Si-treated wheat plants accumulated higher levels of soluble sugars than those of the stressed plants receiving no $\mathrm{Si}$. In Si application treatment, soluble sugar content was $13 \%, 12 \%, 18 \%$ and $20 \%$ higher than that in no Si application under moisture shortage regimes in cvs. Shiraz, Marvdasht, Chamran, and Sirvan, respectively (Table 2).

The concentration of soluble proteins decreased in all wheat cultivars; expect cv. Chamran that showed no differences in the soluble proteins, due to the imposition of moisture stress (Table 2). Exogenously applied Si raised the soluble protein content in the wheat plants experiencing moisture stress. The cultivars differed significantly in soluble proteins. For example, cv. Chamran had much higher levels of soluble proteins than those in the other cultivars in both control and moisture stress regimes (Table 2). The leaf free proline was enhanced markedly under water deficiency all varieties, except cv. Shiraz. Externally applied Si caused a marked increase in leaf free proline content in the plants of all wheat cultivars; expect cv. Shiraz that showed no differences in the proline content, experiencing drought stress (Table 2). Of all the cultivars, cv. Marvdasht was highly responsive to Si application regarding proline content.

\section{Activities of key antioxidant enzymes (POD, SOD, APX, and CAT)}

Drought stress amplified the activity of peroxidase (POD) in all four wheat cultivars. The POD activity in cvs. Sirvan and Chamran were markedly higher than that in the other cultivars under water shortage regimes (Table 3). The rise in the activity of POD under water deficit regimes might be an adaptive response. In all four wheat cultivars, Si application slightly increased the POD activity of drought- stressed plants. However, this increase was significant only in cv. Chamran (Table 3). Water shortage regimes caused a marked increase in SOD activity in all wheat cultivars. Si applied to the foliage increased the SOD activity in 
the water-stressed plants, except for cv. Marvdasht (Table 3). However, it was higher in cvs. Sirvan and Chamran (drought tolerant) than that in the two drought sensitive ones (Table 3).

The ascorbate peroxidase (APX) activity was recorded to be increased in all four wheat varieties under moisture stress. The APX activity was higher in Si supplied plants than that in Si free control plants (Table 4). Cultivar Sirvan had higher APX activity than that recorded in the other wheat cultivars under both 100 and 40\% F.C. treatments (Table 4). Water deficit increased the CAT activity, but foliar-applied Si had no significant influence on its activity under both water deficit and control conditions (Table 4).

\section{Mineral nutrients in leaves}

Water deficit increased the $\mathrm{K}$ (Table 5) and $\mathrm{Ca}$ (Table 6) contents in the leaves of four wheat cultivars. The Mg concentration was significantly increased under water deficit in all wheat cultivars except cv. Shiraz (Table 5). The Na concentration was slightly (but not significantly) reduced in drought-treated plants (Table 6). Under drought conditions, the Si fed plants had higher $\mathrm{K}$ concentration than that in the control plants (Table 5). Accumulation of inorganic solutes, K (Table 5) and Ca (Table 6) in cv. Sirvan was higher than that in the other cultivars under water deficit conditions.

\section{Leaf water potential $\left(\Psi_{w}\right)$}

Water deficit reduced the leaf water potential $\left(\Psi_{\mathrm{w}}\right)$ in all four wheat cultivars. However, significant differences among cultivars were observed with respect to this physiological attribute (Table 7). Cultivars Sirvan and Chamran had higher $\Psi_{\mathrm{w}}$ than the other cultivars under water deficit conditions. Si treatment increased the $\Psi_{\mathrm{w}}$ under water deficit conditions and the highest $\Psi_{\mathrm{w}}$ was observed in cv. Sirvan (Table 7). 


\section{Discussion}

The beneficial effects of soil silicon application have been previously observed on different plants under stressful cues by many workers (e.g., Ma 2004; Gong et al. 2005; Li, Ma, and Shang 2007). However, there is a little evidence on the beneficial role of exogenous application of silicon (Liang et al. 2005; Guevel, Menzies, and Belanger 2007; Hellal et al. 2012; Maghsoudi, Emam, and Ashraf 2015, 2016). Data reported here showed the beneficial effects of foliar application of silicon ( $\mathrm{Si}$ ) on antioxidant activity, accumulation of osmolytes the stability of pollen grains and maintenance of leaf water potential $\left(\Psi_{\mathrm{w}}\right)$ in wheat plants under water deficit regimes, which suggests enhanced water deficit resistance in wheat plants. Increased antioxidant enzyme activities such as APX, POD, CAT, and SOD (Tables 3, 4) and levels of non-enzymatic antioxidants such sugars, proteins and proline (Table 2) could alleviate drought stress-induced adverse effects. Similar findings have been reported in some earlier published studies (Xu et al. 2008; Ashraf 2009). Furthermore, Molassiotis et al. (2006) also reported that oxidative damage could occur due to the accumulation of ROS which may result in lipid and protein oxidation. Moller, Jensen, and Hansson (2007) suggested that the balance between ROS production and activities of antioxidant enzymes is a good determinant of ascertaining the occurrence of oxidative signaling. The potential of counteracting ROS and mitigating their injurious effects relate to the plant drought resistance (Tsugane et al. 1999). Our findings are analogous to those reported by other workers who applied Si to the soil. For example, adding of Si to the soil enhanced leaf antioxidant activity under saline regimes in plants (Liang 1999; Liang et al. 2003). Liang (1999) suggested that Si-fed barley plants operate metabolic pathways that scavenge ROS. ROS-induced injury referred to as oxidative stress, is the premier cause of damage in plants subjected to stressful cues such as drought (Price, Atherton, and Hendry 1989) and temperature (McKersie et al. 1993). Zhu et al. (2004) reported that it is not clearly known whether the Si-induced reduced oxidative injury in wheat 
plants is due to improved antioxidant defense mechanism or water status. It was observed that Si application improved the water status of the leaf tissues which could result in less dehydration and less ROS enzymatic activities, thereby causing less oxidative stress.

The osmoregulatory role of pollen grain area ratio has previously been noticed by Morgan (1999). Our results also implied that pollen grain area ratio could be used as an indicator of osmoregulation as well as drought tolerance in wheat cultivars. This ratio was found greater than 1 under 50 to $30 \%$ PEG solutions for the drought tolerant cultivars Chamran and Sirvan, whereas, it was less than 1 for the drought sensitive cvs. Shiraz and Marvdasht (Table 1). Indeed, Chamran and Sirvan cultivars had greater capability for osmoregulation. In this study pollen area ratio of wheat cultivars treated with silicon, under 50 to $30 \%$ PEG solutions was greater compared to that of control treatment (Table 1, Figure 1, Figure 2). In other words, silicon application improved the stability of pollen grains of wheat cultivars under water deficit.

In this study, it was found that proline, soluble sugars and protein concentrations were significantly increased in wheat leaves under water deficit regimes and it was more marked in the drought tolerant cvs. Sirvan and Chamran (Table 2). The positive role of proline, soluble sugars and protein in osmoregulation is widely reported (Sonobe et al. 2011). Szabados and Savoure (2009) suggested that the proline accumulation in plant tissues may play an effective role in earlier mentioned and may play a critical function in plant drought resistance. Proline is also known to protect protein structure by acting as a chaperone and thereby improving the activities of key enzymes involved in the mechanism of drought tolerance (Ashraf and Foolad 2007). Although Si application markedly enhanced the levels of soluble sugars and free proline in wheat plants under water limited regimes, it is still unclear how Si does this.

The pattern of accumulation of inorganic ions $\left(\mathrm{K}^{+}, \mathrm{Mg}^{2+}, \mathrm{Ca}^{2+}\right.$ and $\left.\mathrm{Na}^{+}\right)$is believed to be related to stress tolerance in most plants. These ions also substantially contribute to 
osmoregulation (Zhu et al. 2005). In this study, concentrations of $\mathrm{K}^{+}, \mathrm{Ca}^{2+}$, and $\mathrm{Mg}^{2+}$ increased in wheat leaf tissues under drought conditions (Tables 5 and 6). Foliar application of Si resulted in enhancing $\mathrm{K}$ concentrations in the leaf tissues of wheat plants grown under water deficit regimes (Table 5).

Leaf water potential $\left(\Psi_{\mathrm{w}}\right)$ is a potential criterion to assess plant water status and it relates to plant photosynthetic capacity (Endres et al. 2010). In our study, the droughttolerant cv. Sirvan maintained considerably higher leaf $\Psi_{\mathrm{w}}$ than the other cultivars under water- limited regimes (Table 7). Furthermore, Si supply improved the leaf water potential of the stressed plants of all four cultivars (Table 7). Similar to our results, in some earlier published reports, the exogenous application of Si has been reported to increase $\Psi_{\mathrm{w}}$ under water deficit regimes (Matoh, Murata, and Takahashi 1991; Gong et al. 2005). However, the role of $\mathrm{Si}$ in plant water uptake and osmoregulation under drought stress is not well understood. The osmolyte levels of the Si-fed wheat plants under water -limited regimes were higher than those in the plants exposed to drought stress alone (Tables 2, 5, 6).

Morgan (1999) was of the view that cultivars with higher osmoregulation capability, maintain higher growth under drought stress. He also reported a close association between osmotic adjustment and biomass production in wheat grown under water- limited conditions. Overall, we have presented data which indicate that the responses of two drought sensitive cultivars, Shiraz and Marvdasht to drought could be modified with silicon supply. In fact, sensitive cultivars treated with Si performed similarly to the tolerant cultivars. Furthermore, the response of pollen grains showed that pollen area ratio under 50 to $30 \%$ PEG was significantly increased in cvs. Shiraz and Marvdash by Si application (Table 1). We also noticed that antioxidant enzymes' activities of susceptible cultivars resembled those of resistant cultivars upon silicon application (Tables 3, 4). 


\section{Conclusions}

The findings reported in the present investigation show the effective role of $\mathrm{Si}$ in the regulation of drought tolerance in wheat plants. They suggest the active role of Si in plant physiological activities including oxidative defense system and water status. Also, Si-treated plants showed an enhanced rate of osmotic adjustment by accumulating osmolytes. These results show that the exogenous application of $\mathrm{Si}$ as a foliar spray is an effective means of mitigating the adverse effects of drought stress on wheat plants.

\section{References}

Ashraf, M. 2009. Biotechnological approach of improving plant salt tolerance using antioxidants as markers. Biotechnology Advances 27:84-93.

Ashraf, M., and M. R. Foolad. 2007. Roles of glycine betaine and proline in improving plant abiotic stress resistance. Environmental and Experimental Botany 59:206-216.

Ashraf, M., R. Rahmatullah, M. Ahmad, M. Afzal, A. Tahir, S. Kanwal, and M. A. Maqsood. 2009. Potassium and silicon improve yield and juice quality in sugarcane Saccharum

officinarum L.) under salt stress. Journal of Agronomy and Crop Science 195:284291.

Bates, L. S., R. P. Waldran, and I. D. Teare. 1973. Rapid determination of free proline for water studies. Plant and Soil 39:205-208.

Bor, M., F. Ozdemir, and I. Turkan. 2003. The effect of salt stress on lipid peroxidation and antioxidants in leaves of sugar beet Beta vulgaris L and wild beet Beta maritime L. Plant Science 164:77-84.

Bradford, M. M. 1976. A rapid and sensitive method for the quantitation of microgram quantities of protein utilizing the principle of protein-dye binding. Analytical Biochemistry 72: 248-254. 
Cakmak, I., D. Strbac, and H. Marschner. 1993. Activities of hydrogen peroxide-scavenging enzymes in germinating wheat seeds. Journal of Experimental Botany 44:127-132.

Costa, R. C. L., A. K. S. Lobato, J. A. G. Silveira, and I. V. Laughinghouse. 2011. ABAmediated proline synthesis in cowpea leaves exposed to water deficiency and rehydration. Turkish Journal of Agriculture and Forestry 35:309-317.

Dhindsa, R. S., and W. Matow. 1981. Drought tolerance in two mosses: correlated with enzymatic defense against lipid peroxidation. Journal of Experimental Botany 32:7991.

Endres, L., J. V. Silva, V. M. Ferreira, G. Ver, and D. S. Barbosa. 2010. Photosynthesis and Water Relations in Brazilian Sugarcane. The Open Agriculture Journal 4:31-37.

Feng, J. P., Q. H. Shi, X. F. Wang, M. Wei, F. J. Yang, and H. N. Xu. 2010. Silicon supplementation ameliorated the inhibition of photosynthesis and nitrate metabolism by cadmium (Cd) toxicity in Cucumis sativus L. Scientia Horticulturae 123:521-530.

Gong, H., X. Zhu, K. Chen, S. Wang, and C. Zhang. 2005. Silicon alleviates oxidative damage of wheat plants in pots under drought. Plant Science 169:313-321.

Gong, H. J., K. M. Chen, Z. G. Zhao, G. C. Chen, and W. J. Zhou. 2008. Effects of silicon on defense of wheat against oxidative stress under drought at different developmental stages. Biologia Plantarum 52:592-596.

Guevel, M. H., J. G. Menzies, and R. R. Belanger. 2007. Effect of root and foliar applications of soluble silicon on powdery mildew control and growth of wheat plants. European Journal of Plant Pathology 119:429-436.

Guo, Z., W. Ou, S. Lu, and Q. Zhong. 2006. Differential responses of antioxidative system to chilling and drought in four rice cultivars differing in sensitivity. Plant Physiology and Biochemistry 44:828-836. 
Hamada, A. M., and A. E. EL-Enany. 1994. Effect of $\mathrm{NaCl}$ salinity on growth, pigment and mineral element contents, and gas exchange of broad bean and pea plants. Biologia Plantarum 36:75-81.

Hattori, T., S. Inanaga, H. Araki, P. An, S. Mortia, M. Luxova, and A. Lux. 2005. Application of Si enhanced drought tolerance in sorghum bicolor. Physiologia Plantarum 123:459-466.

Hellal, F. A., M. Abdelhameid, M. Abo-Basha Doaa, and R. M. Zewainy. 2012. Alleviation of the adverse effects of soil salinity stress by foliar application of silicon on faba bean (Vica faba L.). Journal of Applied Sciences Research 8:4428-4433.

Hummel, I., F. Pantin, R. Sulpice, M. Piques, G. Rolland, M. Dauzat, A. Christophe, M. Pervent, M. Bouteille, M. Stitt, Y. Gibon, and B. P. Muller. 2010. Arabidopsis plants acclimate to water deficit at low cost through changes of carbon usage: an integrated perspective using growth, metabolite, enzyme, and gene expression analysis. American Society of Plant Biologists 154:357-372.

Khanna-Chopra, R., and D. S. Selote. 2007. Acclimation to drought stress generates oxidative stress tolerance in drought-resistant than-susceptible wheat cultivar under field conditions. Environmental and Experimental Botany 60:276-283.

Li, Q. F., C. C. Ma, and Q. L. Shang. 2007. Effects of silicon on photosynthesis and antioxidative enzymes of maize under drought stress. Chinese Journal of Applied Ecology 18:531-536.

Liang, Y. 1999. Effects of silicon on enzyme activity and sodium, potassium and calcium concentration in barley under salt stress. Plant and Soil 209:217-224.

Liang, Y., Q. Chen, Q. Liu, W. Zhang, and R. Ding. 2003. Exogenous silicon (Si) increases antioxidant enzyme activity and reduces lipid peroxidation in roots of salt-stressed barley (Hordeum vulgare L.). Journal of Plant Physiology 160:1157-1164. 
Liang, Y. C., W. C. Sun, J. Si, and V. Romheld. 2005. Effects of foliar- and root-applied silicon on the enhancement of induced resistance to powdery mildew in Cucumis sativus. Plant Pathology 54:678-685.

Liang, Y. C., J. Zhu, and Z. J. Li. 2008. Role of silicon in enhancing resistance to freezing stress in two contrasting winter wheat cultivars. Environmental and Experimental Botany 64:286-294.

Lobato, A. K. S., C. F. Oliveira Neto, B. G. Santos Filho, R. C. L. Costa, F. J. R. Cruz, H. K. B. Neves, and M. J. S. Lopes. 2008. Physiological and biochemical behavior in soybean (Glycine max cv. Sambaiba) plants under water deficit. Australian Journal of Crop Science 2:25-32.

Ma, J.F. 2004. Role of silicen in enhancing the resistance of plants to biotic and abiotic stresses. Soil Seience and Plant Nutrition 50:11-18.

Maghsoudi, K., Y. Emam, and M. Ashraf. 2016. Foliar application of silicon at different growth stages alters growth and yield of selected wheat cultivars. Journal of Plant Nutrition 39:1194-1203

Maghsoudi, K., Y. Emam, and M. Ashraf. 2015. Influence of foliar application of silicon on chlorophyll fluorescence, photosynthetic pigments, and growth in water-stressed wheat cultivars differing in drought tolerance. Turkish Journal of Botany 39:625-634.

Maghsoudi, K., Y. Emam., M. Ashraf, and M.J. Arvin. 2019. Alleviation of field water stress in wheat cultivars using silicon and salicylic acid applied separately or in combination. Crop and Pasture Science 70:36-43.

Maghsoudi, K., Y. Emam., A. Niazi., M. Pessarakli and M.J. Arvin. 2018. P5CS expression level and proline accumulation in the sensitive and tolerant wheat cultivars under control and drought stress conditions in the presence/absence of silicon and salicylic acid. Journal of Plant Interactions 13:461-471. 
Matoh, T., S. Murata, and E. Takahashi. 1991. Effect of silicate application on photosynthesis of rice plants (in Japanese). Japanese Journal of Soil Science and Plant Nutrition $62: 248-251$.

McKersie, B. D., Y. Chen, M. De Beus, S. R. Bowley, and C. Bowler. 1993. Superoxide dismutase enhances tolerance of freezing stress in transgenic alfalfa (Medicago sativa L.). Plant Physiology 103:1155-1163.

Ming, D. F., Z. F. Pei, M. S. Naeem, H. J. Gong, and W. J. Zhou. 2012. Silicon alleviates PEG-induced water-deficit stress in upland rice seedlings by enhancing osmotic adjustment. Journal of Agronomy and Crop Science 198:14-26.

Mittler, R. 2006. Abiotic stress, the field environment and stress combination. Trends in Plant Science 11:15-19.

Molassiotis, A., T. Sotiropoulos, G. Tanou, G. Diamantidis, and I. Therios. 2006. Boroninduced oxidative damage and antioxidant and nucleolytic responses in shoot tips culture of the apple rootstock EM9 (Malusdom estica Borkh). Environmental and Experimental Botany 56:54-62.

Moller, I. M., P. E. Jensen, and A. Hansson. 2007. Oxidative modifications to cellular components in plants. Annual Review of Plant Biology 58:459-481.

Morgan, J. M. 1980. Osmotic adjustment in the spikelets and leaves of wheat. Journal of Experimental Botany 31:655-65.

Morgan, P. W. 1990. Effects of abiotic stresses on plant hormone systems. Plant Biology $12: 113-146$.

Morgan, J. M. 1999. Pollen grain expression of a gene controlling differences in osmoregulation in wheat leaves: a simple breeding method. Australian Journal of Agricultural Research 50:953-62.

Morgan, J. M., and M. K. Tan. 1996. Chromosomal location of a wheat osmoregulation gene 
using RFLP analysis. Australian Journal of Plant Physiology 123:803-806.

Nakano, Y., and K. Asada. 1981. Hydrogen peroxide is scavenged by ascorbate-specific peroxidase in spinach chloroplasts. Plant and Cell Physiology 22:867-880.

Price, A. H., N. Atherton, and G. A. F. Hendry. 1989. Plants under drought stress generated activated oxygen. Free Radical Research Communications 8:61-66.

Raghu, V., K. Platela, and K. Srinivasan. 2007. Comparison of ascorbic acid content of Emblica officinalis fruits determined by different analytical methods. Journal of Food Composition and Analysis 20:529-533.

Reddy, A. R., K. V. Chiatanya, and M. Vivekanandan. 2004. Drought induced responses of photosynthesis and antioxidant metabolism in higher plants. Journal of Plant Physiology 161:1189-1202.

Rontein, D., G. Basset, and A. D. Hanson. 2002. Metabolic engineering of osmoprotectant accumulation in plants. Metabolic Engineering 4:49-59.

Ryan, J., G. Estefan, and A. Rashid. 2007. Soil and plant analysis laboratory manual. International Center for Agricultural Research in the Dry Areas (ICARDA).

Shen, X., Y. Zhou, L. Duan, Z. Li, A. E. Eneji, and J. Li. 2010. Si effects on photosynthesis and antioxidant parameters of soybean seedlings under drought and ultraviolet - B radiation. Journal of Plant Physiology 167:1248-1252.

Sonobe, K., T. Hattori, P. An, W. Tsuji, A. E. Eneji, S. Kobayashi, Y. Kawamura, K. Tanaka, and S. Inanaga. 2011. Effect of silicon application on sorghum root responses to water stress. Journal of Plant Nutrition 34:71-82.

Szabados, L., and A. Savoure. 2009. Proline: a multifunctional amino acid. Trends in Plant Science 15:89-97.

Teixeira, J., and S. Pereira. 2007. High salinity and drought act on an organ-dependent manner on potato glutamine synthetase expression and accumulation. Environmental 
and Experimental Botany 60:121-126.

Tsugane, K., K. Kobayashi, Y. Niwa, Y. Ohba, K. Wada, and H. Kobayashi. 1999. A recessive Arabidopsis mutant that grows photoautotrophically under salt stress shows enhanced active oxygen detoxification. Plant Cell 11:1195-1206.

Xu, P. L., Y. K. Guo, J. G. Bai, L. Shang, and X. J. Wang. 2008. Effects of long-term chilling on ultrastructure and antioxidant activity in leaves of two cucumber cultivars under low light. Physiologia Plantarum 132:467-478.

Yordanov, I., V. Velikova, and T. Tsonev. 2000. Plant responses to drought, acclimation, and stress tolerance. Photosynthetica 38:171-186.

Zhang, Z. J., H. Z. Li, W. J. Zhou, Y. Takeuchi, and K. Yoneyama. 2006. Effect of 5aminolevulinic acid on development and salt tolerance of potato (Solanum tuberosum L.) microtubers in vitro. Plant Growth Regulation 49:27-34.

Zhu, X., H. Gong, G. Chen, S. Wang, and C. Zhang. 2005. Different solute levels in two spring wheat cultivars induced by progressive field water stress at different developmental stages. Journal of Arid Environments 62:1-14.

Zhu, Z., G. Wei, J. Li, Q. Qian, and J. Yu. 2004. Silicon alleviates salt stress and increases antioxidant enzymes activity in leaves of salt-stressed cucumber (Cucumis sativus L.). Plant Science 167:527-533. 
Table 1. Projected pollen grain area under PEG 30\% and PEG 50\% and pollen grain area ratio of wheat cultivars with and without Si application. $(n=10)$.

\begin{tabular}{|c|c|c|c|c|}
\hline \multirow[t]{2}{*}{ Cultivar } & \multirow{2}{*}{$\begin{array}{c}\mathrm{Si} \\
\text { application }\end{array}$} & \multicolumn{2}{|c|}{$\begin{array}{l}\text { Projected pollen grain area } \\
\qquad\left(\mu \mathrm{m}^{2}\right)\end{array}$} & \multirow{2}{*}{$\begin{array}{l}\text { Pollen grain area ratio } \\
\quad(\text { PEG50/PEG30) }\end{array}$} \\
\hline & & PEG 30\% & PEG 50\% & \\
\hline \multirow{2}{*}{ Shiraz } & - & $1.50 \mathrm{c}$ & $1.25 \mathrm{~h}$ & $0.83 \mathrm{f}$ \\
\hline & + & $1.52 \mathrm{c}$ & $1.36 \mathrm{fg}$ & $0.89 \mathrm{e}$ \\
\hline \multirow{2}{*}{ Marvdasht } & - & $1.65 \mathrm{~b}$ & $1.33 \mathrm{f}$ & $0.80 \mathrm{~d}$ \\
\hline & + & $1.64 \mathrm{~b}$ & $1.50 \mathrm{e}$ & $0.91 \mathrm{c}$ \\
\hline \multirow{2}{*}{ Chamran } & - & $1.70 \mathrm{a}$ & $1.70 \mathrm{~cd}$ & $1.00 \mathrm{~b}$ \\
\hline & + & $1.70 \mathrm{a}$ & $1.74 \mathrm{c}$ & $1.02 \mathrm{~b}$ \\
\hline \multirow{2}{*}{ Sirvan } & - & $1.66 \mathrm{ab}$ & $1.89 \mathrm{ab}$ & $1.13 \mathrm{a}$ \\
\hline & + & $1.68 \mathrm{a}$ & $1.92 \mathrm{a}$ & $1.14 \mathrm{a}$ \\
\hline \multicolumn{2}{|c|}{ Standard deviation } & 0.06 & 0.22 & 0.13 \\
\hline
\end{tabular}

Means followed by the same letters within each column do not differ significantly based on Duncan's multiple-range test at 5\% probability level.

Table 2. Influence of $\mathrm{Si}$ on the concentrations of leaves soluble sugars, proteins and free proline of drought tolerant wheat cultivars (Sirvan and Chamran) and sensitive cultivars (Shiraz and Marvdasht) under water deficit. ( $n=4)$.

\begin{tabular}{|c|c|c|c|c|c|c|c|c|c|c|c|c|c|}
\hline \multirow[t]{2}{*}{ Drought } & \multirow[t]{2}{*}{$\mathrm{Si}$} & \multicolumn{4}{|c|}{$\begin{array}{l}\text { Soluble sugars } \\
\left(\mathrm{mg} \mathrm{g}^{-1} \mathrm{DW}\right)\end{array}$} & \multicolumn{4}{|c|}{$\begin{array}{c}\text { Proteins } \\
\left(\mathrm{mg} \mathrm{g}^{-1} \mathrm{DW}\right)\end{array}$} & \multicolumn{4}{|c|}{$\begin{array}{c}\text { Proline } \\
\left(\mathrm{mg} \mathrm{g}^{-1} \mathrm{DW}\right)\end{array}$} \\
\hline & & Sirvan & Chamran & Shiraz & Marvdasht & Sirvan & Chamran & Shiraz & Marvdasht & Sirvan & Chamran & Shiraz & Marvdasht \\
\hline $100 \%$ & - & $45.01 \mathrm{~d}$ & $41.11 \mathrm{~d}$ & 39.10de & $40.02 d$ & $36.61 b$ & $49.07 \mathrm{a}$ & $35.05 \mathrm{~b}$ & $40.67 b$ & $4.19 \mathrm{gh}$ & $4.56 \mathrm{~g}$ & $4.50 \mathrm{~g}$ & $4.83 \mathrm{~g}$ \\
\hline F.C. & + & $42.00 \mathrm{~d}$ & $41.10 \mathrm{~d}$ & $40.00 \mathrm{~d}$ & $43.00 \mathrm{~d}$ & $37.6 \mathrm{~b}$ & $48.00 \mathrm{a}$ & $37.50 \mathrm{~b}$ & $38.58 b$ & $4.62 \mathrm{~g}$ & $4.50 \mathrm{~g}$ & $4.47 \mathrm{~g}$ & $4.64 \mathrm{~g}$ \\
\hline $40 \%$ & - & $59.42 \mathrm{~b}$ & $58.32 \mathrm{~b}$ & $48.05 \mathrm{c}$ & $49.01 \mathrm{c}$ & $33.05 \mathrm{c}$ & $46.97 \mathrm{a}$ & $25.88 \mathrm{~d}$ & $24.41 d$ & $18.24 b$ & $14.48 \mathrm{~d}$ & $5.51 \mathrm{~g}$ & $8.01 \mathrm{f}$ \\
\hline F.C. & + & $75.36 \mathrm{a}$ & $72.31 \mathrm{a}$ & $55.10 \mathrm{bc}$ & $58.14 \mathrm{~b}$ & $37.50 \mathrm{~b}$ & $46.00 \mathrm{a}$ & $34.10 \mathrm{c}$ & $32.06 \mathrm{c}$ & $20.57 \mathrm{a}$ & $16.04 \mathrm{c}$ & $5.64 \mathrm{~g}$ & $10.86 \mathrm{e}$ \\
\hline \multicolumn{2}{|c|}{$\begin{array}{l}\text { Standard } \\
\text { deviation }\end{array}$} & \multicolumn{4}{|c|}{11.00} & \multicolumn{4}{|c|}{6.12} & \multicolumn{4}{|c|}{5.14} \\
\hline
\end{tabular}

Means followed by the same letters for each parameter do not differ significantly based on Duncan's multiple-range test at 5\% probability level.

Table 3. Influence of Si on leaves peroxidase (POD) and superoxide dismutase (SOD) of tolerant wheat cultivars, Sirvan and Chamran and sensitive cultivars, Shiraz and Marvdasht under water deficit $(\mathrm{n}=4)$.

\begin{tabular}{|c|c|c|c|c|c|c|c|c|c|}
\hline \multirow{2}{*}{ Drought } & \multirow{2}{*}{$\mathrm{Si}$} & \multicolumn{4}{|c|}{ POD (U/mg protein) } & \multicolumn{4}{|c|}{ SOD (U/mg protein) } \\
\hline & & Sirvan & Chamran & Shiraz & Marvdasht & Sirvan & Chamran & Shiraz & Marvdasht \\
\hline \multirow{2}{*}{$100 \%$ F.C. } & - & $35.10 \mathrm{de}$ & $35.27 \mathrm{de}$ & $29.31 \mathrm{f}$ & $24.42 \mathrm{~g}$ & $4.09 \mathrm{~d}$ & $4.11 \mathrm{~d}$ & $4.08 \mathrm{~d}$ & $4.10 \mathrm{~d}$ \\
\hline & + & $36.08 \mathrm{de}$ & $35.44 \mathrm{de}$ & $29.37 f$ & $25.36 \mathrm{~g}$ & $4.10 \mathrm{~d}$ & $4.05 \mathrm{~d}$ & $4.12 \mathrm{~d}$ & $4.06 \mathrm{~d}$ \\
\hline \multirow{2}{*}{$40 \%$ F.C. } & - & $44.12 b$ & $41.25 b c$ & $34.54 \mathrm{de}$ & $30.12 \mathrm{f}$ & $7.25 \mathrm{~b}$ & $7.00 \mathrm{~b}$ & $6.12 \mathrm{c}$ & $6.22 \mathrm{c}$ \\
\hline & + & $46.02 b$ & $50.11 \mathrm{a}$ & $37.00 \mathrm{~d}$ & $33.65 \mathrm{ef}$ & $8.29 \mathrm{a}$ & $8.14 \mathrm{a}$ & $6.94 b$ & $6.29 c$ \\
\hline \multicolumn{2}{|c|}{ Standard deviation } & \multicolumn{4}{|c|}{6.70} & \multicolumn{4}{|c|}{1.50} \\
\hline
\end{tabular}

Means followed by the same letters for each parameter do not differ significantly based on Duncan's multiple-range test at 5\% probability level. 
Table 4. Influence of Si on leaves ascorbate peroxidase (APX) and catalase (CAT) of tolerant wheat cultivars, Sirvan and Chamran and sensitive cultivars, Shiraz and Marvdasht under water deficit $(n=4)$.

\begin{tabular}{|c|c|c|c|c|c|c|c|c|c|}
\hline \multirow{2}{*}{ Drought } & \multirow{2}{*}{$\mathrm{Si}$} & \multicolumn{4}{|c|}{ APX (U/mg protein) } & \multicolumn{4}{|c|}{ CAT (U/mg protein) } \\
\hline & & Sirvan & Chamran & Shiraz & Marvdasht & Sirvan & Chamran & Shiraz & Marvdasht \\
\hline \multirow{2}{*}{$100 \%$ F.C. } & - & $1.54 \mathrm{~cd}$ & $1.03 \mathrm{de}$ & $0.92 \mathrm{e}$ & $0.98 \mathrm{e}$ & $2.36 \mathrm{c}$ & $2.54 \mathrm{c}$ & $2.46 \mathrm{c}$ & $2.13 \mathrm{~cd}$ \\
\hline & + & $1.58 \mathrm{c}$ & $1.08 \mathrm{~d}$ & $0.97 \mathrm{e}$ & $0.98 \mathrm{e}$ & $2.35 \mathrm{c}$ & $2.57 \mathrm{c}$ & $2.43 \mathrm{c}$ & $2.15 \mathrm{~cd}$ \\
\hline \multirow{2}{*}{$40 \%$ F.C. } & - & $2.68 b$ & $1.92 \mathrm{c}$ & $1.23 \mathrm{~d}$ & $1.31 \mathrm{~d}$ & $7.54 \mathrm{a}$ & $7.68 \mathrm{a}$ & $6.12 b$ & $6.15 b$ \\
\hline & + & $3.50 \mathrm{a}$ & $2.54 \mathrm{~b}$ & $1.61 \mathrm{c}$ & $1.84 \mathrm{c}$ & $7.61 \mathrm{a}$ & $7.72 \mathrm{a}$ & $6.15 b$ & $6.15 b$ \\
\hline \multicolumn{2}{|c|}{ Standard deviation } & \multicolumn{4}{|c|}{0.73} & \multicolumn{4}{|c|}{2.30} \\
\hline
\end{tabular}

Means followed by the same letters for each parameter do not differ significantly based on Duncan's multiple-range test at 5\% probability level.

Table 5. Influence of $\mathrm{Si}$ on leaves $\mathrm{K}$ and $\mathrm{Mg}$ concentrations of drought tolerant wheat cultivars, Sirvan and Chamran and sensitive cultivars, Shiraz and Marvdasht under drought stress $(n=4)$.

\begin{tabular}{|c|c|c|c|c|c|c|c|c|c|}
\hline \multirow{2}{*}{ Drought } & \multirow{2}{*}{$\mathrm{Si}$} & \multicolumn{4}{|c|}{$\mathrm{K}(\mathrm{mg} / \mathrm{g} \mathrm{DW})$} & \multicolumn{4}{|c|}{$\mathrm{Mg}(\mathrm{mg} / \mathrm{g} \mathrm{DW})$} \\
\hline & & Sirvan & Chamran & Shiraz & Marvdasht & Sirvan & Chamran & Shiraz & Marvdasht \\
\hline \multirow{2}{*}{$100 \%$ F.C. } & - & $42.21 \mathrm{ef}$ & $44.95 \mathrm{de}$ & $40.17 \mathrm{f}$ & $43.24 \mathrm{e}$ & $2.46 \mathrm{~b}$ & $2.45 b$ & $2.38 \mathrm{~b}$ & $2.47 \mathrm{~b}$ \\
\hline & + & $40.87 f$ & $43.62 \mathrm{e}$ & $41.08 \mathrm{f}$ & $41.76 f$ & $2.36 \mathrm{~b}$ & $2.44 b$ & $2.39 b$ & $2.45 b$ \\
\hline \multirow{2}{*}{$40 \%$ F.C. } & - & $60.52 b$ & $54.23 \mathrm{c}$ & $46.63 \mathrm{de}$ & $49.35 \mathrm{~d}$ & $3.50 \mathrm{a}$ & $3.61 \mathrm{a}$ & $2.52 \mathrm{~b}$ & $3.50 \mathrm{a}$ \\
\hline & + & $68.09 \mathrm{a}$ & $60.12 b$ & $52.23 c$ & $54.23 \mathrm{c}$ & $3.46 \mathrm{a}$ & $3.60 \mathrm{a}$ & $2.45 b$ & $3.48 \mathrm{a}$ \\
\hline \multicolumn{2}{|c|}{ Standard deviation } & \multicolumn{4}{|c|}{8.20} & \multicolumn{4}{|c|}{0.52} \\
\hline
\end{tabular}

Means followed by the same letters for each parameter do not differ significantly based on Duncan's multiple-range test at 5\% probability level.

Table 6. Influence of $\mathrm{Si}$ on leaves $\mathrm{Ca}$ and $\mathrm{Na}$ concentrations of drought tolerant wheat cultivars, Sirvan and Chamran and sensitive cultivars, Shiraz and Marvdasht under water deficit $(n=4)$.

\begin{tabular}{|c|c|c|c|c|c|c|c|c|c|}
\hline \multirow{2}{*}{ Drought } & \multirow{2}{*}{$\mathrm{Si}$} & \multicolumn{4}{|c|}{$\mathrm{Ca}(\mathrm{mg} / \mathrm{g} \mathrm{DW})$} & \multicolumn{4}{|c|}{$\mathrm{Na}(\mathrm{mg} / \mathrm{g} \mathrm{DW})$} \\
\hline & & Sirvan & Chamran & Shiraz & Marvdasht & Sirvan & Chamran & Shiraz & Marvdasht \\
\hline \multirow{2}{*}{ 100\% F.C. } & - & $8.32 b c$ & $7.56 \mathrm{c}$ & $8.32 b c$ & $8.00 \mathrm{c}$ & $20.76 a$ & $21.36 \mathrm{a}$ & $20.94 a$ & $21.50 \mathrm{a}$ \\
\hline & + & $8.12 \mathrm{c}$ & $8.00 \mathrm{c}$ & $8.41 b c$ & $7.65 \mathrm{c}$ & $20.01 \mathrm{a}$ & $21.00 \mathrm{a}$ & $20.00 \mathrm{a}$ & $20.00 \mathrm{a}$ \\
\hline \multirow{2}{*}{$40 \%$ F.C. } & - & $11.23 \mathrm{a}$ & $9.10 \mathrm{~b}$ & $9.12 b$ & $9.22 b$ & $19.05 \mathrm{a}$ & $20.38 \mathrm{a}$ & $19.10 \mathrm{a}$ & $20.00 \mathrm{a}$ \\
\hline & + & $11.00 \mathrm{a}$ & $9.08 b$ & $9.13 b$ & $9.15 b$ & $19.12 \mathrm{a}$ & $21.00 \mathrm{a}$ & $19.23 \mathrm{a}$ & $20.12 \mathrm{a}$ \\
\hline \multicolumn{2}{|c|}{ Standard deviation } & \multicolumn{4}{|c|}{1.01} & \multicolumn{4}{|c|}{0.79} \\
\hline
\end{tabular}

Means followed by the same letters for each parameter do not differ significantly based on Duncan's multiple-range test at 5\% probability level. 
Table 7. Influence of Si on leaf water potential $\left(\Psi_{\mathrm{w}}\right)$ of wheat drought tolerant cultivars, Sirvan and Chamran and sensitive cultivars, Shiraz and Marvdasht under water deficit $(n=4)$.

\begin{tabular}{|c|c|c|c|c|c|}
\hline \multirow{2}{*}{ Drought } & \multirow{2}{*}{$\mathrm{Si}$} & \multicolumn{4}{|c|}{$\Psi_{\mathrm{w}}(-\mathrm{MPa})$} \\
\hline & & Sirvan & Chamran & Shiraz & Marvdasht \\
\hline \multirow{2}{*}{$100 \%$ F.C. } & - & $1.70 \mathrm{~g}$ & $1.68 \mathrm{~g}$ & $1.69 \mathrm{~g}$ & $1.70 \mathrm{~g}$ \\
\hline & + & $1.68 \mathrm{~g}$ & $1.70 \mathrm{~g}$ & $1.68 \mathrm{~g}$ & $1.70 \mathrm{~g}$ \\
\hline \multirow{2}{*}{$40 \%$ F.C. } & - & $2.40 \mathrm{~d}$ & $2.65 b$ & $2.95 \mathrm{a}$ & $2.90 \mathrm{a}$ \\
\hline & + & $1.90 \mathrm{f}$ & $2.15 \mathrm{~d}$ & $2.55 \mathrm{c}$ & $2.55 \mathrm{c}$ \\
\hline
\end{tabular}

Means followed by the same letters do not differ significantly based on Duncan's multiple-range test at $5 \%$ probability level.

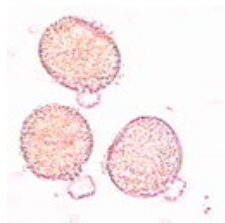

A
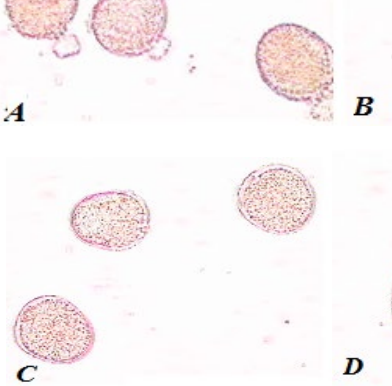

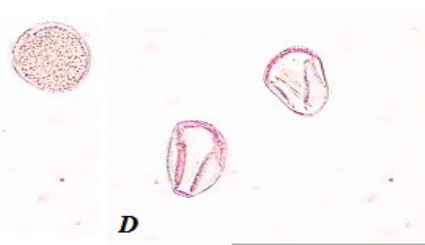

Figure 1. Response of pollen grains of cv. Shiraz to (A): PEG 30\%, (B): PEG 50\%, (C): PEG 30\% plus Si and (D): PEG 50\% plus Si.

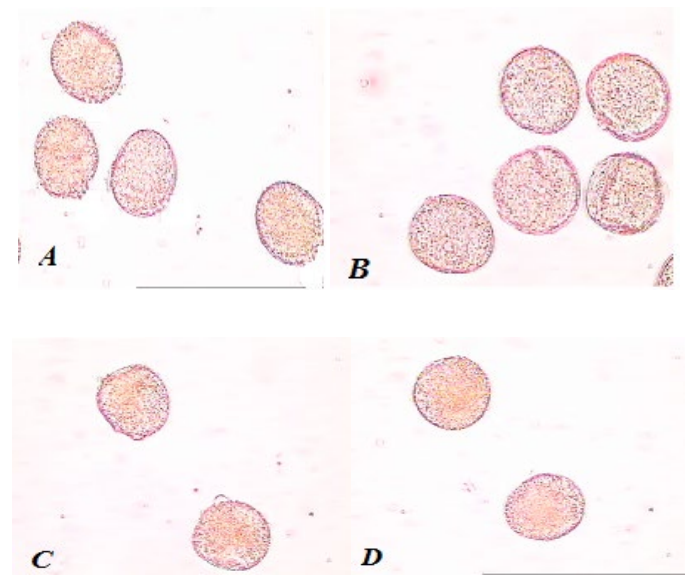

Figure 2. Response of pollen grains of cv. Sirvan to (A): PEG 30\%, (B): PEG 50\%, (C): PEG 30\% plus Si and (D): PEG 50\% plus Si. 